RESEARCH ARTICLE

\title{
Control of crown rot of banana using Carica papaya latex
}

\author{
S. R. P. Indrakeerthi ${ }^{1}$ and N. K. B. Adikaram ${ }^{2 *}$ \\ ${ }^{I}$ National Packaging Center, Export Development Board, 42, Nawam Mawatha, Colombo 2. \\ ${ }^{2}$ Department of Botany, Faculty of Science, University of Peradeniya, Peradeniya.
}

Revised: 05 November 2010 ; Accepted: 21 January 2011

\begin{abstract}
Crown rot, incited by a complex of fungi, is a major cause of postharvest losses in banana. Fusarium semitectum, Colletotrichum musae and C. gloeosporioides were identified as the major crown rot causing fungi in Sri Lanka. In addition Verticillium theobromae and Botryodiplodia theobromae are also associated with the disease. Conidia of major crown rot pathogens, when exposed to the water soluble fraction (WSF) of Carica papaya (papaya) latex underwent complete digestion. A $50 \%$ preparation of WSF digested a dense suspension of C. gloeosporioides conidia within 1 minute. Application of the WSF of papaya latex onto the cut surface of banana crown preinoculated with F. semitectum, C. musae and C. gloeosporioides prevented the development of crown rot. The activity of enzymes in the WSF of latex, particularly the chitinase, could be implicated to the conidia digestion process. The latex is more effective when applied at least 60 minutes after dehanding, allowing sufficient time for crown exudates to dry out. This appears to be due to the coagulation of proteins in papaya latex in the presence of watery exudate of the freshly exposed banana crown. The latex treatment also hardened and induced a black colouration in the exposed crown surface forming a physical barrier to invading pathogens.
\end{abstract}

Keywords: Carica papaya latex, chitinase activity, crown rot pathogens.

\section{INTRODUCTION}

Crown rot of dehanded banana is a major cause of losses during storage and marketing of banana and considered as one of the most serious and frequent postharvest and post-packaging diseases (Khan et al., 2001). All commercial cultivars of desert bananas are known to be susceptible to crown rot.

Many fungi have been reported to be associated with banana crown rot i.e. Fusarium pallidoroseum, Verticillium theobromae, F. moniliformae, Botryodiplodia theobromae, Penicillium coxyophilum, Acrymonium triticina and Nigrospora sphaerica (Griffee \& Burden, 1976; Jones, 1991). The infection takes place at the exposed surface of the crown. Usually the rot is confined to the crown but at advanced stages it spreads into the pedicels of the fingers. With severe infections whitish fungal mycelia and reproductive bodies appear on the rotted crown, finger stalks and finally on the fingers (Griffee \& Burden, 1976).

Application of systemic fungicides is the most common practice for commercial control of banana crown rot (Shillingford, 1976; Cox, 1996; Lassois et al., 2008). Although synthetic fungicides have provided effective control of major postharvest diseases, their application may be harmful to human health and the environment and they become ineffective after prolonged use. Attempts have been made towards crown rot control through cultural, physical and biological (Lassois et al., 2008) methods as an alternative to synthetic fungicides (Dionisio \& Natsuaki, 2007). A considerable reduction of crown rot was achieved by treatment with antagonistic bacteria (Costa \& Subasinghe, 1998), mycoparasites (Krauss et al., 1998), chlorinated water (75-125 ppm) (Snowden, 1990), hot water dips (Lopez-Cabrera \& Marrero-Dominguez, 1998), rapid cooling soon after dehanding (Green \& Goos, 1963), and controlled atmosphere (CA) and modified atmosphere (MA) storage. Essential oils, particularly, basil oil, have been used to effectively control crown rot during cold storage (Anthony et al., 2003). Two 'goldfinger' banana hybrids were found partially resistant to crown rot fungi (Martin et al., 1996).

Plants possess a diverse array of secondary metabolites, which function as fungal inhibitors having a potential to control postharvest diseases in fruits and vegetables (Neri

\footnotetext{
Corresponding author (nkba@pdn.ac.lk)
} 
et al., 2009). The latex of papaya (Carica papaya) fruit contains four major proteases (Howard \& Glazer, 1967), chitinase enzyme (Howard \& Glazer, 1967; Adikaram et al., 1997; Azarkan et al., 1997) and several glycosidases; $\quad p$ NP- $N$-Acetyl- $\beta$-D-glucosaminidase, $\quad p N P-\mu-\mathrm{L}-$ arabinosidase, $p \mathrm{NP}-\beta$-fucosidase, $p \mathrm{NP}-\mu$-D-galactoside, $p$ NP- $\beta$-D-galactosidase, $\quad p N \mathrm{NP}-\mu$-D-glucosidase, $\quad p$ NP$\beta$-D-glucosidase, $p$ NP- $\mu$-mannosidase and $p$ NP- $\beta$-Dxylase (Giordani \& Laurence, 1993; Giordani et al., 1996; Giordani et al., 1991). N-acetyl- $\beta$-D-glucosiminidase (chitinase) activity was particularly high in papaya latex. Strong lipase activity was detected in the water-insoluble particles of papaya latex (Gandhi \& Mukherjee, 2000).

There are no reports on the use of $C$. papaya latex in plant disease control. This paper examines the fungicidal properties of papaya latex and the possibility of its use in the control of banana crown rot.

\section{METHODS AND MATERIALS}

Plant materials and fungal isolates: Fruits of banana cultivar 'Ambun' (AAA) were used for the experiments described in this paper. Freshly harvested bunches of banana at harvesting maturity (13 wks after anthesis) were obtained from the market at Peradeniya, brought to the University of Peradeniya and dehanded using a clean, sharp knife. The banana hands were washed with running tap water before being used for experiments.

Isolation and identification of fungi associated with the crown rot samples collected: Crowns of banana cultivar 'Ambun' with or without crown rot symptoms were collected from retail fruit stalls in and around Kandy (Central Province) by twice a month visits for a period of one year. The collected crowns were stored in the laboratory in separate moist chambers at room temperature $\left(26 \pm 2{ }^{\circ} \mathrm{C}\right)$. The development of crown rot was visually examined. Tissue segments and scrapings obtained periodically from infected sites were observed under the medium/high power of light microscope and some fungi associated with the diseased tissues were identified. Infected tissue segments were surface sterilized with $\mathrm{NaOCl}$ and transferred onto Cook's No. 2 agar and the plates were incubated at $26 \pm 2{ }^{\circ} \mathrm{C}$. Fungal colonies that appeared were sub-cultured and identified using colony characteristics, morphology and size of conidiophore and conidia size and arrangement. Length and width of 100 conidia were measured using an eye-piece graticule at $X$ 400 magnification and averaged. The succession of fungi that appeared during crown rot development was studied in a separate set of hands, incubated at $26 \pm 2{ }^{\circ} \mathrm{C}$.

F. semitectum, C. musae, $V$. theobromae,
C. gloeosporioides and B. theobromae isolated from diseased crowns in the study and isolates of Pestalotiopsis sp., C. capsici, Nectria sp., Sordaria musae, Trichoderma sp., Penicillium sp., Phoma sp., Aspergillus sp., Rhizopus arrhizus and Alternaria sp. maintained in the laboratory collection were sub-cultured on to Cook's No. 2 medium and used for the experiments.

Artificial inoculation of banana crowns with the pathogens isolated: Suspensions of conidia of 5 crown rot pathogens, C. gloeosporioides, F. semitectum, C. musae, B. theobromae and $V$. theobromae were prepared separately. Mycelia scraped from 6-8 d cultures were suspended in sterile distilled water and the suspensions were shaken to dislodge conidia and filtered through glass wool. The conidia were washed by repeated centrifugation and re-suspension in fresh sterile distilled water, and the concentration of conidia was adjusted to $10^{6}$ conidia $\mathrm{mL}^{-1}$. Equal amounts from the 5 conidia suspensions were mixed together to prepare a mixed suspension of conidia. A combination of dual conidia suspensions was prepared by mixing equal amounts of conidia suspensions of two crown rot pathogens at a time.

A bunch of mature unripe banana, free of any visible damage or disease symptoms, was dehanded by cutting through the crown very close to the main stalk. The banana hands were washed with running tap water and kept on a layer of 3-4 clean tissues in order to drain off the excess water and allow the banana latex to drain off from freshly exposed crown tissue. Three banana crowns were inoculated by applying $200 \mu \mathrm{L}$ of a mixed suspension of conidia on each freshly exposed crown tissue using a clean soft paint brush. Sterile distilled water $(200 \mu \mathrm{L})$ was applied on another 3 banana crowns as controls. Both treated and control sets of banana hands were incubated first in moist chambers for $6 \mathrm{~d}$ at room temperature $\left(26^{\circ} \pm 2{ }^{\circ} \mathrm{C}\right)$ and then transferred to laboratory shelves. The development of crown rot symptoms was observed and the extent of disease was assessed by using a scale based on the depth of the crown infected from the surface, daily for 8-10 d after inoculation and expressed as the extent of disease in a percentage. A cardboard strip (1 $\mathrm{cm}$ in width) cut to the size of the depth of each crown (distance between the crown surface and the finger stalks) was divided into 8 equal segments, one segment representing $12.5 \%$ of crown depth. The extent of crown rot was determined by placing the strip at 3 locations on the upper surface of the crown and the mean value was calculated. Different paper strips had to be made for each banana crown used. The appearance of fungi in succession was followed up to the $6^{\text {th }}$ day by visual examination of inoclulated crowns and the mycelium of fungi under microscope. The experiment was repeated twice. 
Collection of latex from papaya fruit and preparation of water soluble fraction (WSF), freeze-dried and solar dried powder: The surface of immature, green papaya (C. papaya cv. Solo Hawaii Round) fruit was cleaned by wiping with a cotton wool swab soaked with $70 \%$ ethanol and allowed to dry. Latex was collected from the fruit into a measuring cylinder by making 5 surface incisions (2-3 $\mathrm{mm}$ deep) along the long axis using a clean blade. The freshly collected latex was diluted 10 times by adding sterile distilled water and stirred. This was then centrifuged at $3000 \mathrm{rpm}$ for $10 \mathrm{~min}$. The supernatant, which contains the WSF was carefully decanted into a sterile beaker.

A $100 \mathrm{~mL}$ portion of the WSF of papaya latex was freeze-dried (Labconco,USA) at $-50{ }^{\circ} \mathrm{C}$ and 600 PSI for 2-3 $\mathrm{d}$ and the powder was stored in an airtight round bottom flask at $-18{ }^{\circ} \mathrm{C}$ until use. Solar dried papaya latex was prepared by allowing freshly collected latex to solidify in a watch glass for 2-3 min and prolonged sun drying for 18 h (Nadarajah et al., 1973).

Fungicidal property of the WSF of papaya latex: Conidia suspensions $\left(5 \times 10^{5} \mathrm{~mL}^{-1}\right)$ of crown rot pathogens (F. semitectum, C. musae, C. gloeosporioides, $B$. theobromae and $V$. theobromae) and Pestalotiopsis sp., C. capsici, Nectria sp., Sordaria musae, Trichoderma sp., Penicillium sp., Phoma sp., Aspergillus sp., Rhizopus arrhizus and Alternaria sp. maintained in the laboratory collection were prepared. Aliquots $(1 \mathrm{~mL})$ were pipetted into separate glass tubes, each containing $2 \mathrm{~mL}$ portions of $10 \% \mathrm{WSF}$ and mixed well. Drops $(20 \mu \mathrm{L})$ from each mixture were immediately placed on clean glass slides. Four slides each with two drops were prepared for each pathogen. The conidia were observed under light microscope (10 x 40) at $5 \mathrm{~min}$ intervals for $1 \mathrm{~h}$. The total number of conidia per microscopic field and the number of deformed or destroyed conidia were counted and recorded. Ten microscopic fields were observed per conidia suspension. The procedure was repeated using a series of dilutions containing $1 \%, 10 \%$, $20 \%, 30 \%, 40 \%$ and $50 \%$ WSF. The time taken for $100 \%$ digestioin of conidia in each dilution was also recorded. The experiment was repeated.

Conidia of some fungi were not visually affected by WSF within $1 \mathrm{~h}$ of exposure. Fresh conidia suspensions of these fungi were prepared. Four drops $(20 \mu \mathrm{L})$ of banana latex $(10 \%)$ were placed on two glass slides (two drops per slide). Drops $(20 \mu \mathrm{L})$ of conidia of a pathogen were added onto each latex drop and mixed using a sterile needle. The suspensions of conidia mixed with equal volumes of sterile distilled water or $10 \%$ glucose solution instead of papaya latex, were used as controls. The slides were kept in a moist chamber for $24 \mathrm{~h}$ at room temperature.
The conidia, which showed neither disintegration nor germination in the presence of the WSF within $24 \mathrm{~h}$ were collected in drops, pooled and mixed with sterile distilled water and centrifuged repeatedly with five changes of fresh sterile distilled water at $3000 \mathrm{rpm}$ in order to wash off the latex. The washed conidia were suspended in $10 \%$ glucose and allowed to germinate on glass slides. The percentage germination was determined.

Rot development in crowns pre-treated with the WSF of papaya latex: A bunch of mature, unripe banana was dehanded and the hands were washed with running tap water and allowed to dry for $1 \mathrm{~h}$. Aliquots $(200 \mu \mathrm{L})$ of WSF of papaya latex were applied onto the cut surface of the crown of 4 hands using a fine paint brush. Another set of 4 hands was treated with the systemic fungicide, benlate $(0.45 \mathrm{~g} / \mathrm{L}$ Benomyl $50 \mathrm{w} / \mathrm{w}$, Lankem). One set was treated with sterile distilled water and another untreated set served as controls. The crowns were inoculated with a mixed suspension $(200 \mu \mathrm{L})$ of conidia of C. musae, $C$. gloeosporioides and $F$. semitectum and incubated. Crown rot development was recorded over a period of $10-12 \mathrm{~d}$ by using a scale based on the depth of the crown infected as described previously.

To find out the best time of crown treatment after dehanding, 7 sets each containing 4 hands were prepared. One set was treated with $200 \mu \mathrm{L}$ WSF soon after dehanding $(\mathrm{t}=0)$ using a paint brush. The remaining sets of banana clusters were similarly treated with $200 \mu \mathrm{L}$ of WSF 15, 30, 45, 60, 90 and 120 min after dehanding. All treated clusters were inoculated with $200 \mu \mathrm{L}$ of a mixed suspension of conidia of $C$. musae, C. gloeosporioides and $F$. semitectum and incubated at room temperature. The crown rot development was recorded for $10-12 \mathrm{~d}$. The experiment was repeated twice.

Analysis of data: Data were subjected to analysis of variance (ANOVA) using MINITAB 11.12 software package.

\section{RESULTS}

Fungi associated with banana crown rot samples collected

The diseased banana crowns collected had whitish or greyish fungal growth and blackened crown surface. In severely infected crowns the rot had progressed into the finger stalks. Microscopic examinations of scrapings of heavily infected banana crowns showed the presence of conidia of several fungi. Five fungi were isolated and identified using their colony characteristics, morphology, 
size and arrangement of conidiophores and conidia. F. semitectum (CMI descriptions of pathogenic fungi and bacteria, 1970), and C. musae were isolated from all fifteen samples whereas $C$. gloeosporioides, $V$. theobromae (CMI descriptions of pathogenic fungi and bacteria, 1978) and $B$. theobromae were isolated at frequencies $73.3 \%, 80 \%$ and $53.8 \%$ of the crowns examined, respectively. Several other unidentified fungi were also present.

Artificial inoculation of banana crowns with fungi isolated from diseased crowns and their re-isolation

Crown rot symptoms were observed in all banana crowns artificially inoculated with a mixed suspension of conidia of F. semitectum, C. gloeosporioides and C. musae, at different frequencies within 3-6 days. Fruits had fully ripened on the $5^{\text {th }}$ day. The average crown rot was $96.8 \%$ on the $8^{\text {th }}$ day and the controls also had an average of $42.2 \%$ crown rot. F. semitectum, C. gloeosporioides and C. musae could be re-isolated from all artificially inoculated crowns at a frequency of $100 \%$. V. theobromae and B. theobromae were isolated at a lesser frequency; $75 \%$ and $25 \%$ respectively. F. semitectum appeared first 3 days after the inoculation. C. musae and V. theobromae were observed 4 and 6 days after inoculation, respectively.

Rot development in the entire crown surface was observed within 10 days when inoculated with only F. semitectum. The rot development was less (75\%) when crowns were inoculated with conidia of only C. musae. C. gloeosporioides alone developed $43.8 \%$, whereas $V$. theobromae (37.5\%) and B. theobromae (18.8\%) developed significantly $(\mathrm{p}=0.05)$ smaller rots (Table 1$)$ when inoculated individually.

Crowns when inoculated with mixtures of conidia of either F. semitectum and C. musae or F. semitectum and C. gloeosporioides developed $100 \%$ crown rot within 10 days. The crowns inoculated with a mixed suspension of conidia of $F$. semitectum and $V$. theobromae also developed larger (94\%) crown rots while moderate crown rot development was observed in crowns inoculated with combinations of $F$. semitectum and B. theobromae, $C$. musae and C. gloeosporioides, C. musae and $V$. theobromae. The least crown rot development was observed in crowns inoculated with combinations, C. musae and B. theobromae, C. gloeosporioides and $B$. theobromae, C. gloeosporioides and V. theobromae and $V$. theobromae, and B. theobromae (Table 1).

In artificial inoculations the pathogens appeared to colnize the crown tissue in succession. F. semitectum was the first fungus to colonize the crown tissue and C. musae appeared next, 1-2 days later. C. gloeosporioides was detected at a latter stage followed by $V$. theobromae and B. theobromae.

\section{Properties of WSF of papaya latex}

Fresh WSF of papaya latex was a clear, colourless liquid with a mild characteristic smell. When the WSF was stored at room temperature, it became cloudy and off-white due to bacterial growth and later developed an unpleasant odour. Freeze-dried WSF of fresh papaya latex was a crispy, white powder and a $100 \mathrm{~mL}$ portion of $10 \% \mathrm{WSF}$ yielded $7 \mathrm{~g}$. Solar dried papaya latex appeared brownish yellow in colour.

Table 1: Crown rot development in banana cv. 'Ambun' following inoculation with crown rot pathogens, individually or different combinations and stored for 6 days at $26+2^{\circ} \mathrm{C}$.

\begin{tabular}{lrl}
\hline Pathogen/s & \% crown rot development* \\
\hline C. musae $(\mathrm{Cm})$ & $75.8 \pm 5.7^{* *}$ \\
F. semitectum $(\mathrm{Fs})$ & $100.0 \pm 0.0$ \\
C. gloeosporioides $(\mathrm{Cg})$ & $46.9 \pm 2.6$ \\
V. theobromae $(\mathrm{Vt})$ & $34.6 \pm 1.0$ \\
B. theobromae $(\mathrm{Bt})$ & $18.7 \pm 1.2$ \\
F. semitectum + C. musae & $100.0 \pm 0.0$ \\
F. semitectum + C. gloeosporioides & $100.0 \pm 0.0$ \\
F. semitectum + V. theobromae & $89.1 \pm 1.4$ \\
F. semitectum + B. theobromae & $50.0 \pm 9.9$ \\
C. musae + C. gloeosporioides & $45.3 \pm 14.6$ \\
C. musae + V. theobromae & $57.8 \pm 6.6$ \\
C. musae + B. theobromae & $28.1 \pm 8.1$ \\
C. gloeosporioides + V. theobromae & $21.9 \pm 4.9$ \\
C. gloeosporioides + B. theobromae & $18.7 \pm 2.2$ \\
V. theobromae + B. theobromae & $26.6 \pm 2.7$ \\
Control & $18.5 \pm 2.0$ \\
\hline
\end{tabular}

* Extent of disease was assessed using a scale based on the depth of the crown tissue infected from the cut surface

** Values indicate the mean \pm standard error of 4 replicates

\section{Effect of WSF of papaya latex on conidia/spores of some pathogenic fungi}

The WSF affected the fungi tested in the study in different ways. The conidia of F. semitectum, C. musae, C. gloeosporioides and C. capsici became digested completely in the presence of WSF (Table 2). The time taken for complete digestion in a $10 \%$ preparation of WSF was 6-10 minutes for $F$. semitectum whereas for C. gloeosporioides and C. musae it was 15 minutes and 30 minutes respectively. Degradation of conidial walls could be clearly observed under the light microscope (Figure 1). 
Sporangiospores of $R$. arrhizus and conidia of Alternaria sp. could remain intact in the WSF and germinate within 24-36 hours forming germ tubes. Conidia of $V$. theobromae, B. theobromae, Nectria sp., Sordaria musae, Trichoderma sp. and $P$. musarum did not show any germination or digestion in WSF (Table 2). However, the conidia, when removed following exposure to WSF and washed, were able to germinate in a $10 \%$ solution of glucose. Penicillium sp., Phoma sp., Aspergillus sp. and Pestalotia sp. were not visually affected by the WSF. The conidia when removed from WSF after exposure, washed and transferred to $10 \%$ glucose, failed to germinate. Among the fungi, $F$. semitectum was the fastest to be digested in the presence of $10 \% \mathrm{WSF}$ whereas C. musae was the slowest. Conidia

Table 2: Effect of papaya latex on conidia/spores of selected fungi

\begin{tabular}{ll}
\hline Effect of papaya latex & Fungus \\
\hline Complete digestion of conidia & $\begin{array}{l}\text { F. semitectum, C. musae, } \\
\text { C. gloeosporioides, } \text { C. capsici }\end{array}$ \\
$\begin{array}{l}\text { Fungicidal effect without } \\
\text { apparent damage to conidia }\end{array}$ & $\begin{array}{l}\text { Penicillium } \text { sp., Aspergillus sp., } \\
\text { Fungistatic effect }\end{array}$ \\
& $\begin{array}{l}\text { V. theobromae, } \text { B. theobromae, } \\
\text { Nectria } \text { sp., Sodaria musae, } \\
\text { Trichoderma } \text { sp., } \text { P. musarum }\end{array}$ \\
Stimulatory to germination & R. arrhizus, Alternaria sp. \\
\hline
\end{tabular}

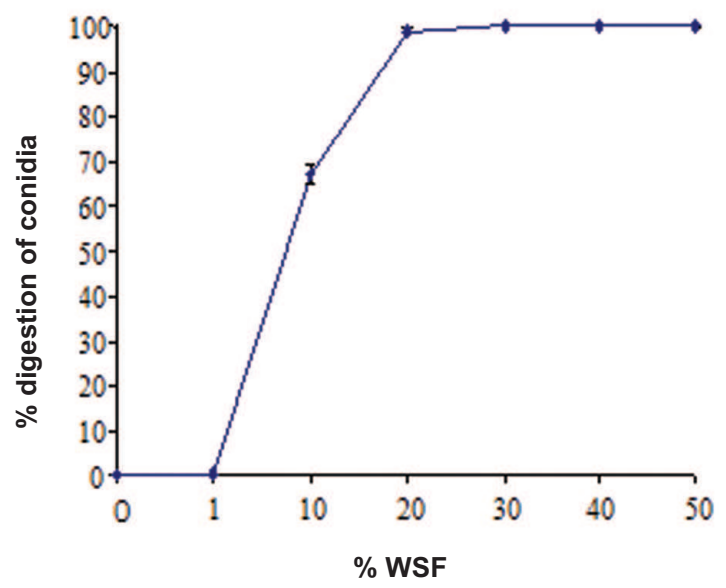

Figure 2: Percent digestion of conidia of $C$. gloeosporioides when exposed to WSF at different concentrations for $15 \mathrm{~min}$ at $26+2^{\circ} \mathrm{C}$. of $C$. gloeosporioides were digested at a moderate rate. $C$. gloeosporioides was used for subsequent experiments of this study.

A $1 \%$ preparation of WSF could not cause any digestion of conidia of $C$. gloeosporioides, during a period of 15 minutes exposure (Figure 2). Prolonged exposure for 100 minutes, however, resulted in complete digestion of conidia. The rate of digestion gradually increased with the increase of WSF concentration. Latex at concentrations above $20 \%$ brought $100 \%$ of conidia digestion within 15 minutes (Table 2). The average time taken for complete digestion of conidia at concntrations $10 \%, 20 \%, 30 \%, 40 \%$ and $50 \%$ was $18,10,6,2$ and 1 minutes respectively.
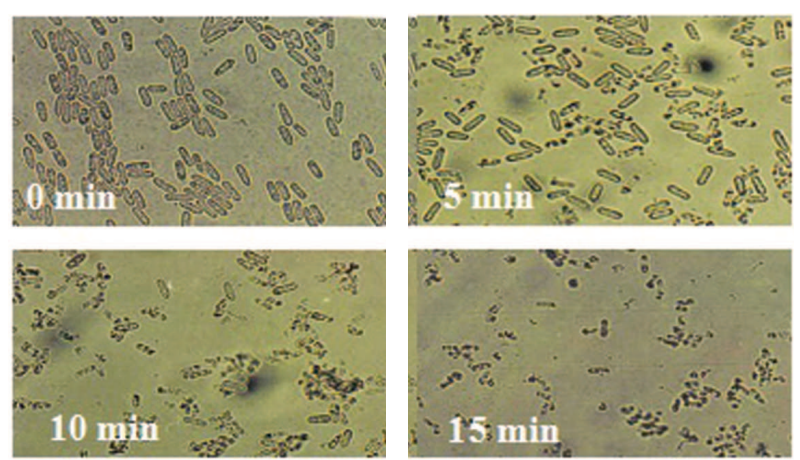

Figure 1: State of conidia of C. gloeosporioides when exposed to WSF $(15 \%)$ of papaya latex over a period of $15 \mathrm{~min}$ at $26+2^{\circ} \mathrm{C}$ seen under microscope (X 600)

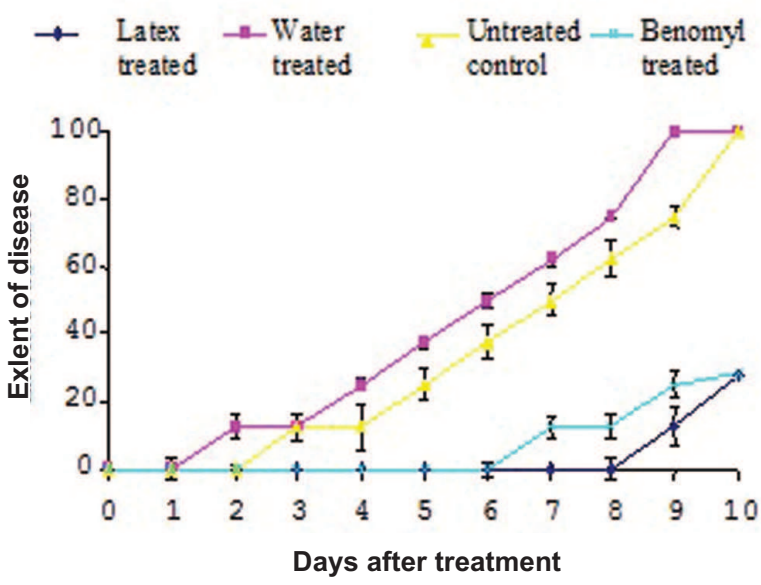

Figure 3: Crown rot development in hands treated with WSF during a 10 day period of storage at $26+2{ }^{\circ} \mathrm{C}$. Extent of crown rot was assessed using a scale based on the depth of the crown tissue infected from the cut surface 
Crown rot development in crowns pre-treated with WSF following inoculation with $C$. gloeosporioides, F. semitectum, C. musae, B. theobromae and $V$. theobromae

Crown rot development began in the untreated control and the one treated with sterile distilled water, 2-3 days after inoculation and rot progressed rapidly covering the entire crown and deep into the finger stalks (Figure 3). The first sign of crown rot development was observed in hands treated with WSF only 9 days after inoculation. At this stage the fruits had fully ripened. The symptoms developed slowly and these had about $20 \%$ crown rot on the $10^{\text {th }}$ day. The hands treated with the systemic fungicide, benlate, showed initial crown rot symptoms on the $7^{\text {th }}$ day after inoculation, showing that papaya latex was more effective in controlling crown rot pathogens than even the fungicide (Figure 3).

\section{Development of crown rot following WSF treatment at different time intervals after dehanding}

Over $80 \%$ crown rot development was observed when the crowns were treated with papaya latex soon after $(\mathrm{t}=$ 0 ) or 15 minutes after dehanding (Table 3). Delaying the treatment by 30,45 and 60 minutes resulted in a progressive reduction of the crown rot development. The results also showed that in order to obtain a $60-70 \%$ reduction, the WSF must be applied at least 60 minutes after dehanding (Table 3). ANOVA showed a significant $(p=0.001)$ effect of time of WSF application after dehanding on crown rot development.

Table 3: Effect of latex treatment at different time intervals after dehanding, on the development of crown rot at $26+2^{\circ} \mathrm{C}$

\begin{tabular}{cc}
\hline $\begin{array}{l}\text { Period between dehanding } \\
\text { and latex treatment (min) }\end{array}$ & $\%$ crown rot development*** \\
\hline 0 & $92.1 \pm 4.2 * *$ \\
15 & $90.6 \pm 2.47$ \\
30 & $66.4 \pm 7.02$ \\
45 & $36.8 \pm 2.28$ \\
60 & $00^{*}$ \\
75 & $00^{*}$ \\
\hline
\end{tabular}

* blackened treated tissue

** Values indicate the mean \pm standard error of 4 replicates

*** Extent of crown rot disease was assessed using a scale based on the depth of the crown tissue infected from the cut surface

\section{DISCUSSION}

Several fungi were found associated with the banana crown rot in Sri Lanka. Among them F. semitectum and C. musae were the most common. Artificial inoculation of crowns with $F$. semitectum alone and in combination with C. musae or C. gloeosporioides produced typical crown rot symptoms in $100 \%$ crowns inoculated. This is also the first fungus to appear in the crown tissue. This study suggests that $F$. semitectum could be the main pathogen causing crown rot in 'Ambun' bananas in Sri Lanka. C. musae is also an important pathogen as it alone produced crown rot at a frequency of $75 \%$. Apart from C. gloeosporioides which could bring about $47 \%$ disease, the other pathogens isolated, B. theobromae or $V$. theobromae, are of minor importance. It is likely that the latter fungi colonize once $C$. musae and $F$. semitectum are established in crown tissue. Earlier reports (Anthony et al., 2003; Sarananda et al., 1994) suggested C. musae to be the main pathogen causing crown rot in the cultivar 'Embul'. Studies carried out elsewhere have emphasized the complexicity of fungi associated with crown rot. The nature of the cut-crown also influenced rot development since badly cut-crowns developed more extensive rot than those that had been trimmed neatly (Finlay et al., 1992). The fungal growth on the main stalk at harvest is a major source of inoculum for crown rot development (Indrakeerthi, 2006). The fresh wounds made on the crown when the hands are severed from the main-stalk proves the main point of entry to invading fungi.

Numerous measures have been adapted to control banana crown rot and most of them are based on the use of synthetic chemicals. In the present study we investigated the possibility of utilising papaya latex as a natural fungicide to control crown rot. Papaya latex displays strong fungicidal activity against many fungi, which include some crown rot pathogens such as C. musae, C. gloeosporioides and $F$. semitectum. The conidia, when exposed directly to papaya latex, undergo rapid digestion and their walls and cell contents become gradually disintegrated. This shows that the papaya latex has a direct, destructive effect on conidia of major crown rot pathogens. Papaya latex is known to possess significant enzyme activity, notably chitinase, proteinase (Charavanapavan, 1945) and lipase (Gandhi \& Mukherjee, 2000). Hydrolytic activity of these enzymes, particularly the chitinase, which could breakdown chitin in the fungal cell walls, could be implicated to the conidia digestion process.

The fungitoxic property of papaya latex, however, varied with different fungi. The latex was highly 
fungicidal to certain fungal species while on other species it inflicted fungistatic effect without causing permanent damage to conidia. There were two exceptional species, notably Rhizopus sp., which not only withstood but also proliferated in the presence of papaya latex. The differential response of some of the fungal species tested here to papaya latex may be related to the composition of their hyphal walls. A major component of the hyphal wall of $C$. gloeosporioides, a highly sensitive fungus to papaya latex, is chitin (Howard \& Glazer, 1967). On the other hand Rhizopus sp. has a smaller percentage of chitin in its hyphal wall and the major constituent is chitosan (Adikaram et al., 1995). The species such as Rhizopus may be overcoming the toxicity of papaya latex by utilising constituents of papaya latex as a source of energy for growth much more rapidly prior to any counter action by the enzymes in the latex. Rhizopus spp. are generally weakly parasitic and show stronger saprophytic growth. There is variation in the percentage spores germinated in the presence of papaya latex among different fungi (Saxena \& Saksena, 1981).

Very few attempts have been made to explore the fungicidal property of papaya latex. Dharmasiri (1988) was the first to observe the fungicidal property of papaya latex where he showed the destruction of conidia of C. gloeosporioides on exposure to papaya latex. He correlated the resistance of immature papaya fruits to C. gloeosporioides to the occurrence of the latex in the skin. This was further confirmed by the fact that latex disappears gradually while ripening, which coincides with postharvest rot development, particularly the anthracnose.

This study has conclusively shown that papaya latex could be effectively used in the control of banana crown rot. Application of water-soluble fraction of papaya latex on the freshly exposed crowns prevented the development of crown rot to a degree comparable to the systemic fungicide, Benlate. The latex can be applied conveniently by using a paint brush. About ten drops $(200 \mu \mathrm{L})$ of WSF is adequate for treatment of one crown. The minimum dilution should be $10 \%$.

Fruits of the latex-treated crowns did not ripen as fast as the controls (S.R.P. Indrakeerthi, unpublished data). While ethylene production by diseased crowns in control hands may have accelerated ripening, a possible retardation of ripening by the action of latex cannot be ruled out. Latex application also resulted in hard, blackish tissue layers on the crown surface. Hardening and blackening of the latextreated crown tissue may have resulted from the action of the latex and could also provide a mechanical or perhaps a chemical barrier to pathogen invasion. The papaya latex applied on the crowns appears to remain active for several hours (Indrakeerthi, 2006). The freshly cut banana crown exudes a watery latex, which remains for few hours before drying out and is able to counter the fungitoxicity of papaya latex, inactivating its proteins and hence enzyme activity (S.R.P. Indrakeerthi, unpublished data). Banana latex is also an excellent medium for growth of crown rot pathogens (Indrakeerthi, 2006). This necessitates the removal of the watery banana latex prior to application of papaya latex on dehanded crowns. Our results indicate that for effective control of crown rot papaya latex must be applied at least 60 -75 minutes after dehanding.

The papaya latex treatment could effectively protect the de-handed banana hands from development of crown rot disease and that papaya latex treatment, while cost effective, is also user- and eco-friendly, convenient and leaves no residual problems.

\section{Acknowledgement}

Authors acknowledge the Council for Agriculture and Research Policy (CARP), Sri Lanka for financial assistance.

\section{REFERENCES}

1. Adikaram N.K.B., Indrakeerthi S.R.P., Abayasekara C., Ranasinghe Menike P.C. \& Karunaratne A. (1995). Antifungal activity in fruits and postharvest disease. Proceedings of the Australasian postharvest horticulture conference, Melbourne, Australia, 18-22 September. Monash Unviersity, Melbourne, Australia, pp. 381-385.

2. Adikaram N.K.B., Karunaratne A., Indrakeerthi S.R.P. \& Menike P.R. (1997). Resistance of immature papaya (Carica papaya L.) fruit to fungal infection: an overview. Proceedings of the international workshop on disease resistance in fruits, ACIAR Proceedings No. 80, Chang Mai, Thailand, 18-21 May. ACIAR, Canberra, Australia, pp. 121-128.

3. Anthony S., Abeywickrama K. \& Wijeratnam S.W. (2003). The effect of spraying essential oils of Cymbopogon flexuosus and Oscimum basilicum on postharvest disease and storage of 'Embul' Banana. Journal of Horticultural Science \& Biotechnology 78(6):780-785.

4. Azarkan M., Amrani A., Nijs M., Vandermeers A., Zerhouni S., Smolders N. \& Looze Y. (1997). Carica papaya latex is a rich source of a class II Chitinase. Phytochemistry 46(8): 1319-1325.

5. Charavanapavan C. (1945). Studies in the preparation, properties and assay of commercial papain. Tropical Agriculturist 51:72.

6. CMI Descriptions of pathogenic fungi and bacteria (1970). No. 259 Fusarium semitectum. Commonwealth Mycologlcal Institute, Kew, Surrey, UK.

7. CMI Descriptions of pathogenic fungi and bacteria (1978). No. 259 Verticillium theobromae. Commonwealth 
Mycologlcal Institute, Kew, Surrey,UK.

8. Costa D.M. de \& Subasinghe S.S.N.S. (1998). Antagonistic bacteria associated with the fruit skin of banana in controlling its postharvest diseases. Tropical Science 38(4):206-212.

9. Cox J. R. (1996). Postharvest treatment of bananas in the Windward Islands. Pests and Diseases 1:373-378.

10. Dharmasiri M.A.N. (1988). A study of papaya anthracnose caused by Colletotrichum gloeosporioides (penz) and $C$. capsici (syd) with special reference to its latent phase. M.phil Thesis, University of Peradeniya, Peradeniya.

11. Dionisio G. A. \& Natsuaki K.T. (2007). Control of crown rot-causing fungal pathogens of banana by inorganic salts and a surfactant. Crop Protection 26 (11):1667-1673.

12. Finlay A.R., Lubin C. \& Brown A.E. (1992). The banana stalk as a source of inoculum of fungal pathogens which cause crown rot. Tropical Science 32(4):343-352.

13. Gandhi N.N. \& Mukherjee K.D. (2000). Specificity of papaya lipase in esterification with respect to the chemical structure of substrates. Journal of Agricultural and Food Chemistry 48(2):566-570.

14. Giordani R., Moulin A. \& Verger R. (1991). Tributyroylglycerol hydrolase activity in Carica papaya and other lattices. Phytochemistry 30(4):1069-1072.

15. Giordani R. \& Laurence L. (1993). Action of Carica papaya latex on cell wall glycosidases from Lacuca sativa pith. Phytochemistry 34(6):1473-1475.

16. Giordani R., Cardinas M.L., Moulin-Traffort J. \& Regli P. (1996). Antifungal activity of latex sap from Carica papaya and antifungal effect of D (+)-glucosamine on Candida albicans growth. Mycoses 39:103-110.

17. Green G.L. \& Goos R.D. (1963). Fungi associated with crown rot of boxed bananas. Phytopathology 53:271-275.

18. Griffee P.J. \& Burden O.J. (1976). Fungi associated with crown rot of boxed bananas in the Windward Islands. Phytopathology 85(2): 149-158.

19. Howard J.B. \& Glazer A.N. (1967). Studies of the physicochemical and enzymatic properties of papaya lysozyme. Journal of Biological Chemistry 242:57155723.

20. Indrakeerthi S.R.P. (2006). Crown rot of banana and its possible control using papaya latex. M.phil. Thesis. University of Peradeniya, Peradeniya.

21. Jones D. R. (1991). Chemical control of crown rot in
Queensland bananas. Australian Journal of Experimental Agriculture 31:693-698.

22. Khan S.H., Aked J. \& Magan N. (2001). Control of the anthracnose pathogen of banana (Colletotrichum musae) using antioxidants alone and in combination with thiobendazole or imazalil. Plant Pathology 50(5): 601608.

23. Krauss U., Bidwell R. \& Ince J. (1998). Isolation and preliminary evaluation of mycoparasites as biocontrol agents of crown rot of banana. Biological Control 13(2):111-119.

24. Lassois L., de Lapeyre de Bellaire L. \& Jijakli M.H. (2008). Biological control of crown rot of bananas with Pichia anomala strain $\mathrm{K}$ and Candida oleophila strain. Biological Control 45(3):410-418.

25. Lopez-Cabrera J. \& Marrero-Domínguez A. (1998). Use of hot water dips to control the incidence of banana crown rot. ISHS Acta Horticulturae 490:563-570.

26. Martin D. H., Sutton T. B., Blankenship S. M. \& Swalloe W.H. (1996). Pathogenecity of fungi associated with crown rot of bananas in Latin America on 'Grande Naine' and disease resistant hybrid bananas. Plant Disease 80(5):525-528.

27. Nadarajah M., Yapa P.A.J., Balasingham C.G. \& Kasinathan S. (1973). The use of papain as a biological coagulant for natural rubber latex. Journal of the Rubber Research Institute of Sri Lanka 50:134-142.

28. Neri F., Mari M., Brigati S. \& Bertolini P. (2009). Control of Neofabraea alba by plant volatile compounds and hot water. Postharvest Biology and Technology 51:425-430.

29. Sarananda K.H., Wijeratnam R.S.W. \& Ariyaratne A.R. (1994). Controlled atmosphere storage of 'Embul' bananas. Tropical Agricultural Research 6:17-22.

30. Saxena A. K. \& Saksena S.B. (1981). Effect of papaya latex on the germination of certain fungi. Phytopathological Notes 34:505-506.

31. Shillingford C.A. (1976). Occurrence of banana fruit rot fungi in Jamaican boxing plants. Plant Disease Reporter 66(9):788-793.

32. Snowdon A.L. (1990). A Colour Atlas of Postharvest Diseases and Disorders of Fruits and Vegetables: volume 1, General Introduction and Fruits, pp. 302. Wolfe Scientific Ltd., London, UK. 